\title{
A van Neck-Odelberg-betegség bemutatása két eset kapcsán
}

\author{
Nagy Örs dr. ${ }^{1}$ - Zuh Sándor-György dr. ${ }^{1}$ - Kovács Attila dr. ${ }^{4}$ \\ Sólyom Árpád dr. ${ }^{2}$ - Sólyom Réka dr. ${ }^{3}$ - Gergely István dr. ${ }^{1}$ \\ Marosvásárhelyi Orvosi és Gyógyszerészeti Egyetem, ${ }^{1}$ I. Ortopédia-Traumatológia Tanszék, \\ ${ }^{2}$ II. Ortopédia-Traumatológia Tanszék, ${ }^{3}$ Gyermekgyógyászati Tanszék, Marosvásárhely, Románia \\ ${ }^{4}$ Maros Megyei Klinikai Kórház, Ortopédia-Traumatológia Klinika, Marosvásárhely, Románia
}

\begin{abstract}
Az osteochondritis ischiopubica (van Neck-Odelberg-betegség) esetében a ramus ossis ischii és a ramus inferior ossis pubis nem megszokott elcsontosodásáról van szó. Klinikai tünetei általában a fájdalom, sántító járás és a csípőízületi mozgáskorlátozottság. A radiológiai kép összetéveszthető egy esetleges töréssel, tumorral vagy gyulladással. Bizonyos esetekben nehézséget okozhat a pontos diagnózis megállapítása és mint elkülönítő kórisme mindenképpen gondolni kell e kórképre. A szerzők két eset ismertetése kapcsán kívánják felhívni a figyelmet e ritka, gyermekkorban jelentkező csontosodási zavar differenciáldiagnosztikai nehézségeire. Orv. Hetil., 2016, 157(21), 836-839.
\end{abstract}

Kulcsszavak: osteochondritis ischiopubica, van Neck-Odelberg, differenciáldiagnózis

\begin{abstract}
Van Neck-Odelberg disease. Report of two cases
Osteochondritis ischiopubica or van Neck-Odelberg disease is characterized by atypical ossification of the ischiopubic synchondrosis. Clinical symptoms are usually pain, limping and limited range of motion of the hip joint. Radiologic images may be confused with the possibility of fracture, tumor or inflammation. In some cases it may be difficult to set up the accurate diagnosis, and during the diagnostic process it is essential that van Neck-Odelberg disease should be considered. In this paper the authors draw attention to this rare disorder and they present the history of two patients who posed diagnostic difficulties.
\end{abstract}

Keywords: osteochondritis ischiopubica, van Neck-Odelberg, differential diagnosis

Nagy, Ö., Zuh, S-Gy., Kovács, A., Sólyom, Á., Sólyom, R., Gergely, I. [Van Neck-Odelberg disease. Report of two cases]. Orv. Hetil., 2016, 157(21), 836-839.

(Beérkezett: 2016. március 11.; elfogadva: 2016. április 7.)

Az ischiopubicus synchondrosis kialakulása a méhen belüli élet ötödik-hatodik hónapjában kezdődik és születéskor szinte teljesen kialakul. A ramus ossis ischii és a ramus inferior ossis pubis közötti synchondrosis még a pubertáskor előtt elcsontosodik [1,2].

$\mathrm{Az}$ ischiopubicus synchondrosis elcsontosodása az esetek egy részében a két oldalt tekintve eltérően és szabálytalanul zajlik. Ez a folyamat általában nem okoz semmilyen klinikai tünetet, azonban egyes gyermekek esetében jelentkezhet lágyéki vagy csípő́izületi fájdalom és mozgáskorlátozottság, valamint sántító járás. A röntgenfelvételen az egyoldali ischiopubicus synchondrosis csontoso- dásának elmaradása észlelhető, ezért a klinikai tünetek, valamint a paraklinikai vizsgálatok nehéz differenciáldiagnosztikai kérdéseket vethetnek fel. Ezen esetekben szóba jöhet fertőzés, törés, endokrin zavar vagy akár tumor jelenléte is [1-4]. A kórkép első leírói van Neck (1924), illetve Odelberg (1923) voltak [5, 6].

Dolgozatunkban ismertetni szeretnénk két esetet, amelyeket a Marosvásárhelyi Ortopédiai és Traumatológiai Klinikán kórisméztünk. Felhívjuk a figyelmet az elkülönítő diagnózis jellegzetességére e ritkán előforduló, a gyermekkorra jellemző csontosodási zavarra. 


\section{Esetbemutatások}

\section{Első beteg}

A 17 éves fiú 2 hete sántított, erős fájdalomra panaszkodott a jobb ischiopubicus régióban. A kórelőzményben nem volt említésre méltó trauma, viszont fontos megemlíteni, hogy aktívan sportolt (futball). Az ischiopubicus synchondrosis duzzanata nem volt észlelhető. Láztalan volt, és nem részesült előzetes gyulladáscsökkentő vagy más gyógyszeres kezelésben. A laboratóriumi vizsgálatok nem mutattak ki kóros eltéréseket, a C-reaktív protein szintje és a vörösvérsejt-süllyedés normális volt.

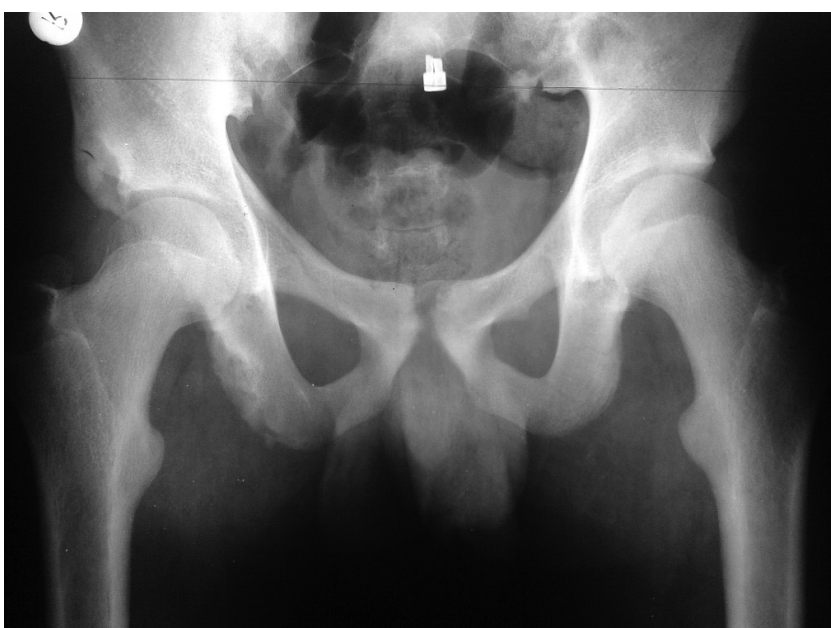

1. ábra Anteroposterior medencefelvétel, a jobb oldali ülőgumó tájékán
felritkulással

Anteroposterior és axiális röntgenfelvételen a jobb medencefélen, az acetabulum alsó pólusán, valamint az ülőgumó szintjén körülírt felritkulás és fragmentáció volt észlelhetô periostealis reakció nélkül (1. ábra). A kismedencei mágneses rezonanciavizsgálat az elváltozás körül oedemát mutatott ki (2. ábra). Mivel a képal-

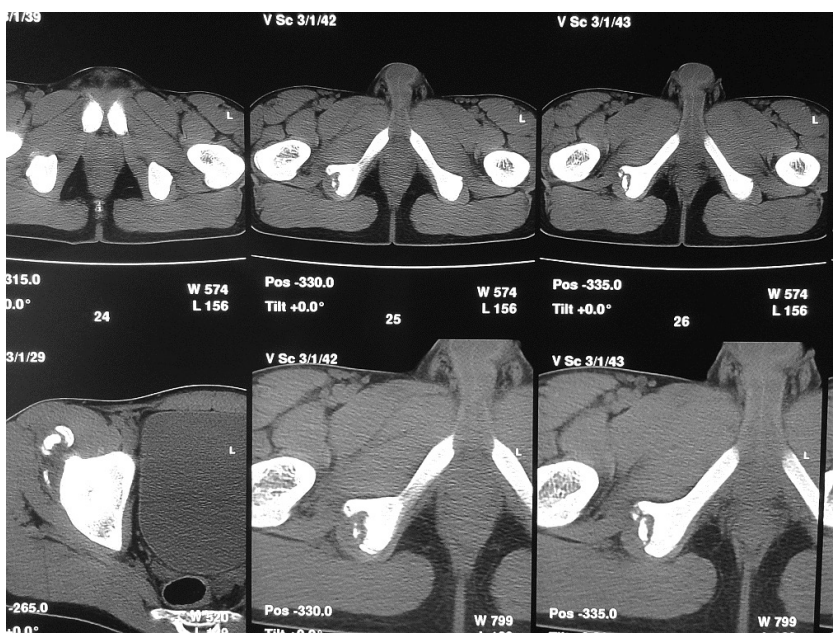

2. ábra $\mid$ Mágneses rezonanciavizsgálat körülírt felritkulást mutat, lágyrész-érintettség nélkül

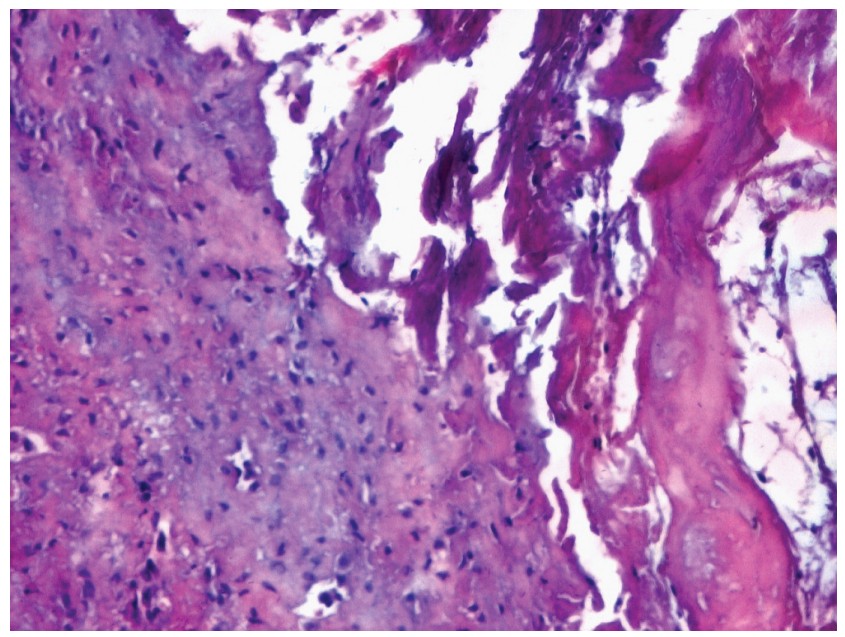

3. ábra

Szövettani kép fibroticus, fragmentált és necroticus csontszövet jelenlétét mutatja (hematoxilin-eozin festés, tízszeres nagyítás)

kotó eljárások nem mutattak jellegzetes elhelyezkedést és elváltozást, a beteg életkorát is figyelembe véve, a biopszia elvégzése elkerülhetetlen volt. A szövettani lelet fibroticus, fragmentált és necroticus csontszövet jelenlétét igazolta (3. ábra). Két hétig tartó gyulladáscsökkentő kezelés és ágynyugalom után a klinikai tünetek javultak. Három, illetve hat hónap után a klinikai és radiológiai kontroll átépülés jeleit mutatta, a beteg fájdalmai megszűntek, panaszmentessé vált.

\section{Második beteg}

A 12 éves lánybeteg szintén jobbcsípő-fájdalom és sántító járás miatt jelentkezett. Említést érdemel, hogy a leány kosárlabdázó volt. Korábban gyógyszeres kezelésben nem részesült. A laboratóriumi vizsgálatok nem mutattak ki kóros eltérést, a vörösvérsejt-süllyedés, C-reaktív protein és az ASLO-titer normális volt. A röntgenfelvétel a jobb ischiopubicus synchondrosis szintjén szabálytalan, felritkult és körülírt fragmentációt mutatott (4. ábra). Kéthetes gyulladáscsökkentő kezelést alkalmaztunk és ágynyugalmat javasoltunk. Ezt követően a klinikai tünetek teljesen megszúntek. A két hónap után elvégzett röntgenfelvételen az érintett részen az átépülés jelei voltak láthatóak (5. ábra). A beteg jelenleg is tünetmentes.

\section{Megbeszélés}

A szakirodalomban leírt megfigyelések alapján az ischiopubicus synchondrosis elcsontosodásának aszimmetriája inkább szabály, mint kivétel [7].

1924-ben van Neck több esetben talált kiszélesedett ischiopubicus synchondrosist. Idővel a folyamat jóindulatúsága, valamint spontán gyógyulási hajlama miatt a betegséget osteochondrosisnak vagy osteochondropathiának nevezték el $[5,6]$. 


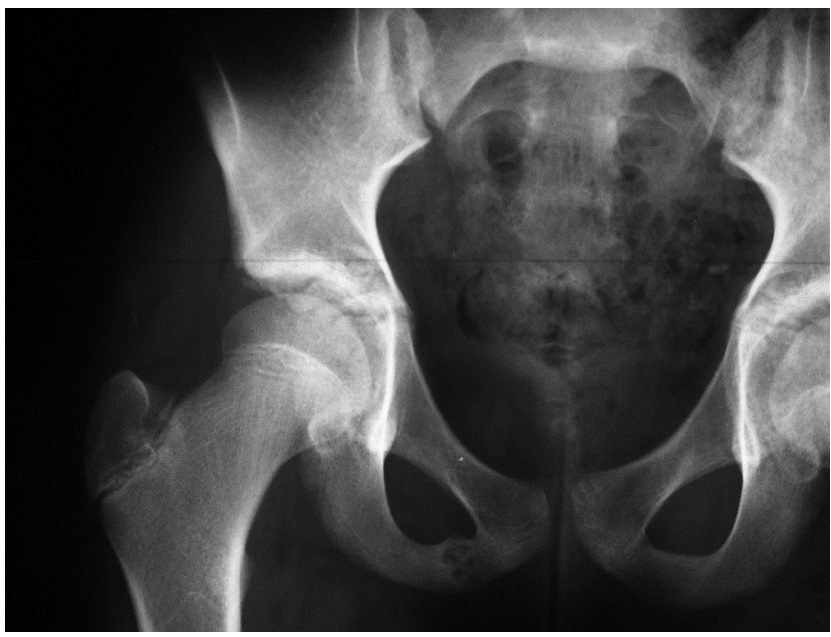

4. ábra

Anteroposterior medencefelvétel, a jobb oldali ischiopubicus synchondrosis tájékán felritkulással

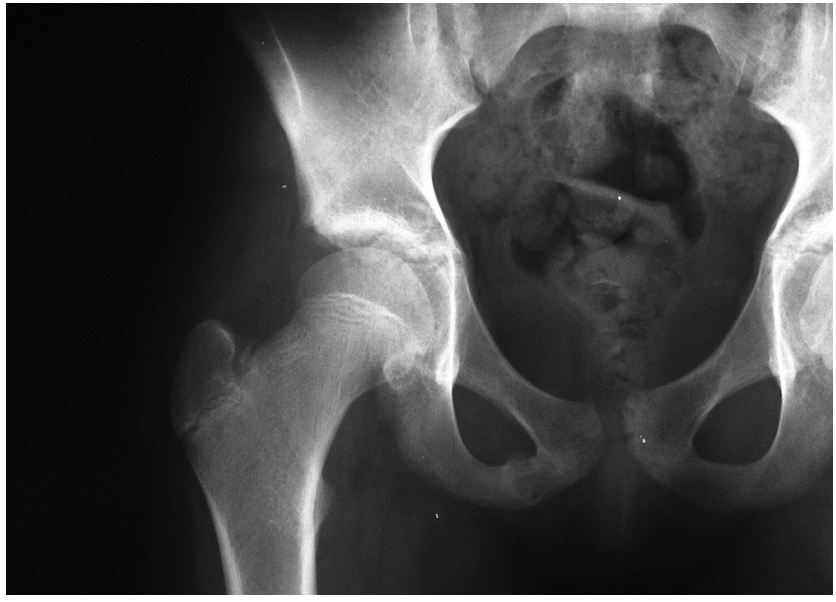

5. ábra

Két hónap múlva a röntgenfelvételen az érintett részen átépülés jelei láthatók

Idősebb gyermekeknél az elcsontosodás teljes befejeződése előtt egyoldalú tágult ischiopubicus synchondrosis gyakran megfigyelhető [7]. Az ischiopubicus synchondrosis aszimmetrikus elcsontosodása, amely fiziológiás jelenségnek könyvelhető el, szoros kapcsolatban van az eltérő helyi mechanikai igénybevétellel, amelyben az adduktor izomzat, az iliopsoas és a musculus gemellus mechanikai túlerőltetése is közrejátszik.

A szakirodalomban közöltek alapján a kétoldali nem egyenlő mechanikai igénybevétel, mint például a rúgás vagy ugrás, okozhatnak gyulladásos reakciót vagy késleltetett teljes csontosodási zavart ezen a szinten $[3,8]$. E gyulladásos reakció késleltetheti a porcréteg egyesülését a csontosodási központtal $[1,9,10]$.

Az ortopéd sebésznek mindig szem előtt kell tartania, hogy a radiológiai, illetve egyéb képalkotó vizsgálat (komputertomográfia, mágneses rezonanciavizsgálat) nehezen kórismézhető elváltozást rejthet.
A járás fájdalmat okoz a csípő- és fartájékon, bicegést és spontán feszülést az adduktorok szintjén, ami nem mindig kapcsolódik egy esetleges traumához. Mindkét betegünknél az ischiopubicus synchondrosis a támasztó láb oldalán jelentkezett, ami valószínúleg arra utalhat, hogy a fiziológiásnál nagyobb erő hatott a nem domináns végtag fizikai megterhelése során.

Herneth felvetett egy esetleges összefüggést az ischiopubicus synchondrosis egyoldalú kiszélesedését illetően a még nem pubertáskorú gyermekek esetében. Véleménye szerint a megnövekedett mechanikai erőbehatás a teherviselő, általában nem domináns lábra hat jobban, mint a lengó lábra, ami általában a domináns [4].

A kórisméhez a hagyományos röntgenfelvétel soha nem elegendő, a betegség könnyen összetéveszthető tumorszerű elváltozással, töréssel, illetve specifikus és nem specifikus gyulladásos folyamattal. Tumorok esetében, mint például a Ewing-sarcománál, általában jelen van a csontdestrukció, a periostealis reakció és a folyamat a lágy szövetekre is ráterjed. Tízéves kor előtt gyakori a Ewingsarcoma előfordulása, a csontos medence szintjén is.

Tízéves kor alatti gyermekeknél ritkábbak a porceredetú daganatok. Az enchondroma vagy chondrosarcoma radiológiai képe eltér az ischiopubicus synchondrosisétól. A mágneses rezonancia- és komputertomográfiás vizsgálat különbséget tud tenni más litikus csontelváltozások, valamint a megnagyobbodott ischiopubicus synchondrosis között.

Az ischiopubicus synchondrosis leggyakoribb szövődménye a stressztörés, amely előfordulhat intenzív fizikai igénybevétel során vagy sugárkezelés után is $[11,12]$.

$\mathrm{Az}$ ischiopubicus synchondrosis közelében található csontszerkezet szövettanilag megegyezik a metaphysisek szintjén található csontszövettel, vénás csatornákkal, ahol a véráramlás lelassul, megteremtve az ideális feltételeket a bakteriális hematogén szórásra $[13,14]$.

A gyermekkorban előforduló akut osteomyelitis általában 5 és 8 éves életkor között fordul elö, és éppen ebben az időszakban találkozhatunk gyakrabban a van Neckszindrómával.

A differenciáldiagnózis néha nehézséget okozhat szubakut, illetve krónikus csontvelőgyulladás, mint például a Brodie-tályog esetében is [15]. Következtetésképpen a pontos etiológiai diagnózis megállapítása nem egyszerü, radiológiai és egyéb képalkotó, illetve laboratóriumi vizsgálat nélkül lehetetlen.

Fontosnak tartjuk a biopszia és a szövettani vizsgálat elvégzését is bizonyos esetekben. A van Neck-Odelbergbetegség ritkán kórismézhető, de a kornak megfelelően mindig gondolnunk kell esetleges jelenlétére. Ezt a tényt próbáltuk bizonyítani az általunk bemutatott két eset kapcsán is.

Anyagi támogatás: A közlemény megírása, illetve a kapcsolódó kutatómunka anyagi támogatásban nem részesült. 
Szerzői munkamegosztás: A cikk megírásában minden szerző részt vett, végleges változatát valamennyi szerző elolvasta és jóváhagyta.

Érdekeltségek: A szerzőknek nincsenek érdekeltségeik.

\section{Irodalom}

[1] Herneth, A. M., Trattnig, S., Bader, T. R., et al.: MR imaging of the ischiopubic synchondrosis. Magn. Reson. Imag., 2000, $18(5), 519-524$.

[2] Caffey, J., Ross, S. E.: The ischiopubic synchondrosis in healthy children: some normal roentgenologic findings. Am. J. Roentgenol. Radium Ther. Nucl. Med., 1956, 76(3), 488-494.

[3] Resnick, D.: Diagnosis of bone and joint disorders. 4th ed. Saunders, Philadelphia, 2002.

[4] Herneth, A. M., Philipp, M. O., Pretterklieber, M. L., et al.: Asymmetric closure of ischiopubic synchondrosis in pediatric patients: correlation with foot dominance. Am. J. Roentgenol., 2004, $182(2), 361-365$.

[5] van Neck, M.: Pubic osteocondritis. [Osteochondrite du pubis.] Arch. Franco-Belg. Chir., 1924, 27, 238-241.

[6] Odelberg, A.: Some cases of destruction in the ischium of doubtful etiology. Acta Chirurg. Scand., 1923-1924, 56, 273-284.

[7] Hübner, L.: Closure rhythm and closure disorders of synchondrosis ischiopubica and their dependence on the pathology of the hip joint (contribution to the clinical aspects of the growing pelvis). Z. Orthop. Ihre Grenzgeb., 1965, 100(1), 38-91.

[8] Kozlowski, K., Hochberger, O., Povysil, B.: Swollen ischiopubic synchondrosis: a dilemma for the radiologist. Australas. Radiol., $1995,39(3), 224-227$.
[9] Neitzschman, H. R.: Radiology case of the month. Hip trauma. Normal physiologic asymmetric closure of the ischiopubic synchondroses. J. Louisiana State Med. Soc., 1997, 149(6), 186188.

[10] Kloiber, R., Udjus, K., McIntyre, W., et al.: The scintigraphic and radiographic appearance of the ischiopubic synchondroses in normal children and in osteomyelitis. Pediatr. Radiol., 1988, $18(1), 57-61$.

[11] Haettich, B., Lebreton, C., Prier, A., et al.: Magnetic resonance imaging of fluorosis and stress fractures due to fluoride. Rev. Rhum. Mal. Osteoartic., 1991, 58(11), 803-808.

[12] Major, N. M., Helms, C. A.: Pelvic stress injuries: the relationship between osteitis pubis (symphysis pubis stress injury) and sacroiliac abnormalities in athletes. Skeletal Radiol., 1997, 26(12), 711-717.

[13] Nixon, G. W.: Hematogenous osteomyelitis of metaphysealequivalent locations. Am. J. Roentgenol., 1978, 130(1), 123129.

[14] Iqbal, A., McKenna, D., Hayes, R., et al.: Osteomyelitis of the ischiopubic synchondrosis: imaging findings. Skeletal Radiol., 2004, 33(3), 176-180.

[15] Kurup, H. W., Uglow, M.: Bilateral asymmetrical Brodie's abscess. Eur. J. Orthop. Surg. Traumatol., 2005, 15(2), 145-147.

(Zuh Sándor-György, Marosvásárbely, Mihai Viteazul utca 31., Románia 540098 e-mail: zuh.sandor@gmail.com)

Az Orvosi Hetilap egyes számai megvásárolhatók a Mediprint Orvosi Könyvesboltban.

Cím: Budapest V., Múzeum krt. 17. - Telefon: 317-4948 